\title{
Diversity of desmid algae (Charophyta: Conjugatophyceae) in the vicinity of Yugorsk city (KMAO-Yugra, Russia)
}

\author{
Andrei S. Shakhmatov* \& Evgeniy V. Pavlovskiy \\ Ural Federal University, Institute of Natural Sciences and Mathematics, Kuybysheva Street 48, \\ 620000 Ekaterinburg, Russia. *E-mail: shahmatov1992@mail.ru
}

\begin{abstract}
The article provides an annotated list, which contains 35 species and subspecific taxa of desmid algae collected in 2015 in swamps near Yugorsk city, West Siberia. Twelve species (Closterium costatum, Cosmarium regnesi, Euastrum ansatum, E. gayanum, E. pulchellum, Staurastrum aculeatum, S. arcuatum var. subavicula, S. tohopekaligense, Staurodesmus dickiei var. circularis, S. glaber, Xanthidium cristatum, X. uncinatum) and one variety (Closterium closterioides var. intermedium) are new for the Khanty-Mansi Autonomous Okrug. Data on morphology and distribution of the species are provided.
\end{abstract}

Keywords: biodiversity, new records, rare species, West Siberia, Desmidiales, Desmidiaceae, Closteriaceae

\section{INTRODUCTION}

Khanty-Mansi Autonomous Okrug - Yugra (KMAO-Yugra) - is one of the largest administrative subjects in the Russian Federation which is situated in the Western Siberia. Algological studies in this territory started in the first half of the 20th century and are actively continuing until present days. During this time, a lot of data on species diversity of various taxonomical groups of algae, especially on desmids, were accumulated (Skvortzow, 1927; Voronikhin, 1930; Naumenko, 1988a, 1988b, 1992, 1996, 2006, 2007; Aleksyuk et al, 1989; Safonova \& Shaulo, 2006, 2007; Romanov, 2008; Skorobogatova \& Naumenko, 2009; Skorobogatova, 2013, 2018; Naumenko \& Ptukhina, 2013; Naumenko \& Gidora, 2014, 2017). Considering the size of the territory of Yugra, which is about $534,800 \mathrm{~km}^{2}$, and the abundance of rivers, lakes and different types of wetlands, there are still a lot of areas not studied from the algological point of view.

Here we report the list comprising 35 taxa of desmid algae collected in the vicinity of Yugorsk city, of which 13 are new for the KMAO-Yugra.

\section{MATERIALS AND METHODS}

The studied area is located near Yugorsk (Fig. 1) - a settlement situated in the western part of West Siberian Plain, at the junction of the North-Sosvinskaya Upland and the Kondinskaya Lowland. The dominant vegetation is middle taiga pine (Pinus sylvestris L.) forests with an abundance of swamps, fens and bogs.
The climate is continental, with moderately cold winter and relatively warm summer. The average temperature in January varies from $-18{ }^{\circ} \mathrm{C}$ to $-20^{\circ} \mathrm{C}$, whereas the average temperature in July is $16-17^{\circ} \mathrm{C}$. The annual amount of precipitation is 430-470 $\mathrm{mm}$ (Gvozdeckiy \& Mikhaylov, 1978; Boch \& Masing, 1979).

The samples of algae were collected in August 2015 by using $40 \mathrm{~mm}$ mesh-size plankton net in mesotrophic sedge fen $\left(61^{\circ} 17^{\prime} 40.8^{\prime \prime} \mathrm{N}\right.$ $\left.63^{\circ} 22^{\prime} 52.2^{\prime \prime} \mathrm{E}\right)$, with banks partially covered by Equisetum sylvaticum L. and Chamerion angustifolium (L.) Holub.

The study of collected material was carried out in a laboratory by using light microscopes Levenhuk 320, Micros MC 50 and Levenhuk C310 NG digital camera. Cell measurements were made using Digimizer v.4.6.1. Species identification was performed by using special literature (Kosinskaya, 1960; Palamar-Mordvintseva, 1982; Coesel \& Meesters, 2007, Coesel \& Meesters, 2013). The validity of taxa was verified with Algaebase (Guiry \& Guiry, 2018).

\section{LIST OF SPECIES}

As a result of the study of the collected material, the following annotated list was compiled. For each taxon the abundance estimation (Ab.: $\mathrm{s}$ - single finding, $\mathrm{r}$ - rare, $\mathrm{c}$ - common, $\mathrm{a}$ - abundant, $\mathrm{m}$ - mass occurrence), cell dimensions (Dim.), short description (Descr.), information 

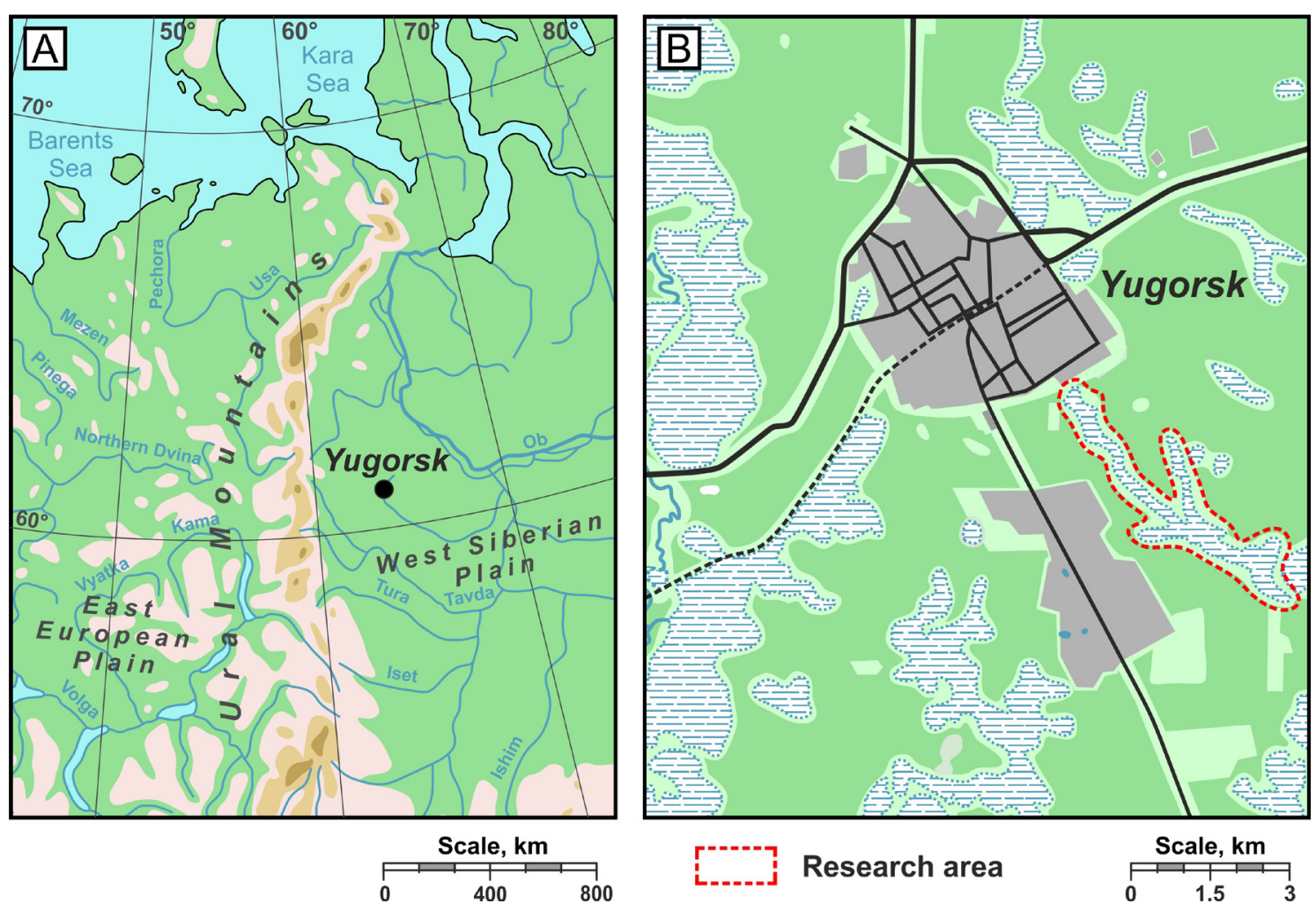

Fig. 1. Location of Yugorsk city in the West Siberian Plain (A) and the research area in its vicinity (B).

about distribution in KMAO-Yugra territory and adjacent regions (Distr.) as well as illustrations are given. Species marked by the asterisk $\left(^{*}\right)$ are new for the territory of the Khanty-Mansi (Yugra) Autonomous Okrug.

\section{Familia Closteriaceae Bessey, 1907}

Closterium acutum var. Linea (Perty) West \& G.S. West, 1900 (Figure 2, 1) - Ab.: r. Dim.: 115.8-185.0 $\mathrm{mm}$ long and 3.6-6.8 $\mathrm{mm}$ wide. Ends 1.3-1.9 mm wide. Descr.: cells almost straight, with a smooth colorless cell wall and acuminate ends. Terminal vacuoles contain 2 small crystals. Distr.: the middle course of $\mathrm{Ob}$ river, without specifying the location (Naumenko, 1992), vicinity of the Nizhnevartovsk city (Safonova \& Shaulo, 2007).

*Closterium Closterioides var. inTERMEdium (J. Roy \& Bisset) Ruzicka, 1973 (Figure 2, 2) - Ab.: c. Dim.: 136.8-140.9 mm long and 27.4-27.9 mm wide. Ends 12.0-13.2 mm wide. Descr.: cells straight, with smooth colorless cell wall and broadly rounded ends. Terminal vacuoles contain numerous small crystals. Distr.: the nearest region where this species has been found is Bolshezemelskaya tundra (Luknitskaya, 1999). Note: the nominate variety of this species, which differs only in having larger cells, is known from the middle course of Ob river (Naumenko, 1992).

*Closterium costatum Corda ex Ralfs, 1848 (Figure 2, 3) - Ab.: s. Dim.: $215 \mathrm{~mm}$ long and $40.1 \mathrm{~mm}$ wide. Ends $12.7 \mathrm{~mm}$ wide. Descr.: cell gradually curved, with costate, brown-colored cell wall, and a ring-like thickening near the broadly rounded ends. Terminal vacuoles contain 1 large crystal. Distr.: the nearest regions where this species has been found is Polar (Briškaite et al., 2016), Middle (Shakhmatov, 2015) and Southern Urals (Snitko \& Sergeeva, 2003; Yarushina et al, 2004).

Closterium GRacile Brébisson, 1848 (Figure 2, 4) - Ab.: c. Dim.: 250.0-256.3 mm long and 5.4-6.4 $\mathrm{mm}$ wide. Ends 2.6-3.4 mm wide. Descr.: cells 


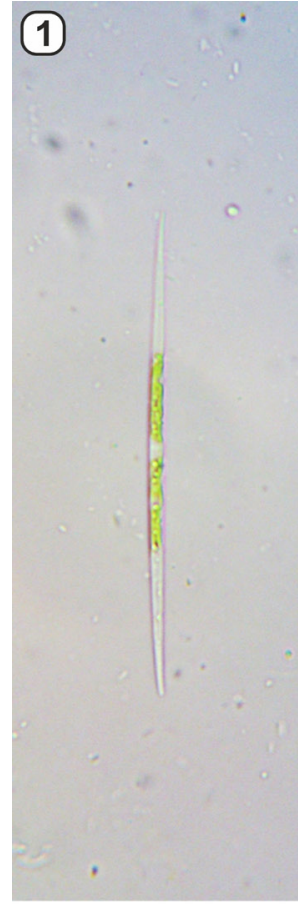

(5)
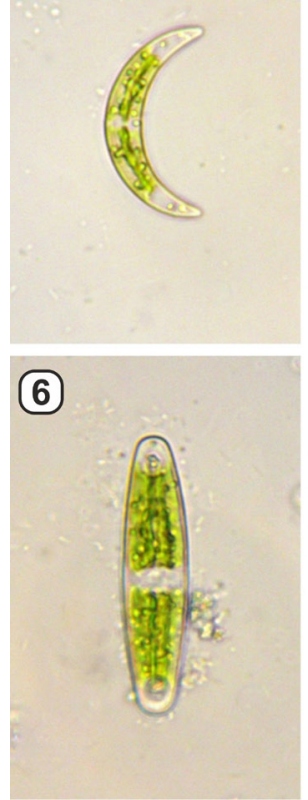

(6)

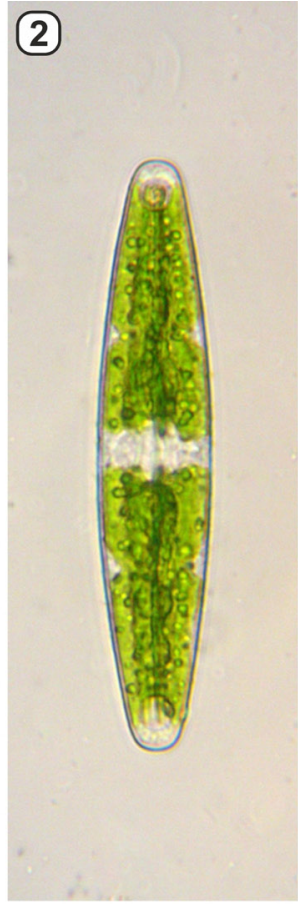

(7)

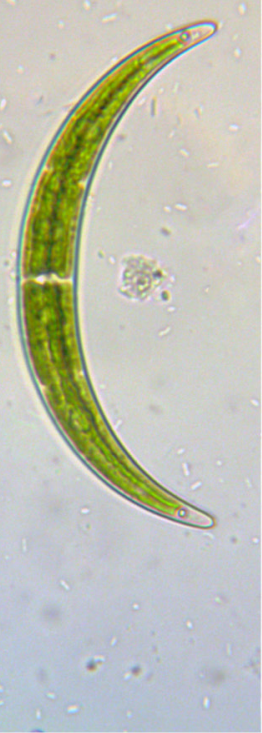

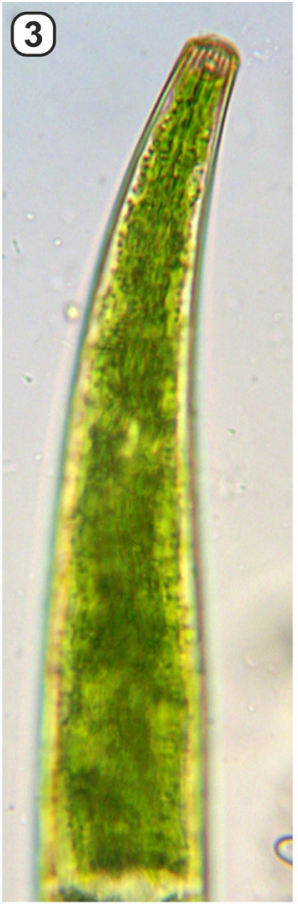

(8)

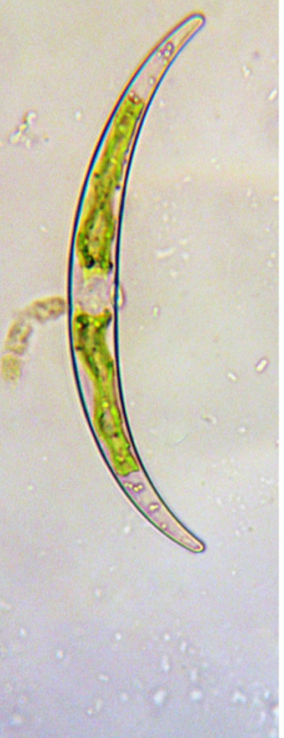

(4)

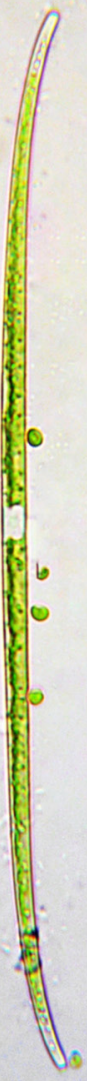

(9)

10

Fig. 2. 1 - Closterium acutum var. linea, 2 - Closterium closterioides var. intermedium, 3 - Closterium costatum, 4 - Closterium gracile, 5 - Closterium incurvum, 6 -Closterium navicula, 7 - Closterium jenneri var. cynthia, 8 - Closterium parvulum, 9 - Cosmarium punctulatum, 10 - Cosmarium regnesi. 
almost straight, slightly curved near the broadly rounded ends. Cell wall smooth and colorless. Terminal vacuoles contain 5 small crystals. Distr.: Konda river (Naumenko, 1988a), Demyanka river (Naumenko, 1988b), Matkinsky and Chaginsky floodplains (Aleksyuk et al., 1989), middle course of $\mathrm{Ob}$ river, without specifying the location (Naumenko, 1992), Vakh river (Skorobogatova \& Naumenko, 2009; Skorobogatova, 2018), Malaya Sosva and Severnaya Sosva rivers (Skorobogatova, 2013).

Closterium INCURVum Brébisson, 1856 (Figure 2, 5) - Ab.: c. Dim.: 64.8-71.0 mm long and 8.6-9.0 mm wide. Ends 2.1-2.7 mm wide. Descr.: cells strongly curved, with smooth colorless cell wall and acuminate ends. Terminal vacuoles contain 2-3 small crystals. Distr.: Seykoryogan river (Naumenko, 2007) and Vakh river (Skorobogatova \& Naumenko, 2009; Skorobogatova, 2018).

Closterium Jenneri var. Cynthia (De Notaris) Petlovany, 2015 (Figure 2, 7) - Ab.: s. Dim.: 154.2 $\mathrm{mm}$ long and $13.6 \mathrm{~mm}$ wide. Ends $4.2 \mathrm{~mm}$ wide. Descr.: cell strongly curved, with striate brown-colored cell wall and broadly rounded ends. Terminal vacuoles contain 1 large crystal. Distr.: Severnaya Sosva river (Skvortzow, 1927).

Closterium navicula (Brébisson) Lütkemüller, 1905 (Figure 2, 6) - Ab.: r. Dim.: 64.1-66.5 mm long and 15.1-15.3 mm wide. Ends 7.9-8.2 $\mathrm{mm}$ wide. Descr.: cells straight, rhomboid in outline, with smooth colorless cell wall and broadly rounded ends. Terminal vacuoles contain 1 large crystal. Distr.: "Sibirskiye uvaly" Nature park (Naumenko, 2006) and vicinity of the Nizhnevartovsk city (Safonova \& Shaulo, 2007).

Closterium Parvulum Nägeli, 1849 (Figure 2, 8) - Ab.: r. Dim.: 143.7-170.8 mm long and 11.8-16.9 mm wide. Ends 3.0-3.5 mm wide. Descr.: cell strongly curved, with smooth colorless cell wall and narrowly rounded ends. Terminal vacuoles contain 5-7 small crystals. Distr.: Naroda river (Voronikhin, 1930), Konda river (Naumenko, 1988a), Demyanka river (Naumenko, 1988b), middle course of Ob river, without specifying the location (Naumenko, 1992), vicinity of the Kirzavod village (Safonova \& Shaulo, 2007), Seykoryogan river (Naumenko, 2006, 2007), Vakh river (Skorobogatova \& Naumenko, 2009; Skorobogatova, 2018), and Sarmsabun river (Naumenko \& Gidora, 2014).

\section{Familia Desmidiaceae Ralfs, 1848}

Cosmarium PUnctulatum Brébisson, 1856 (Figure 2, 9) - Ab.: c. Dim.: 37.5-38.7 $\mathrm{mm}$ long and 33.7-34.5 mm wide. Isthmus 11.4-12.5 $\mu \mathrm{m}$ wide. Descr.: cells square-shaped in outline with deep linear sinus. Semicells with broadly rounded angles and slight inflation in median part. Cell wall granulated. Distr.: Konda river (Naumenko, 1988a) and Sarmsabun river (Naumenko \& Gidora, 2014).

*Cosmarium Regnesi Reinsch, 1866 (Figure 2, 10) - Ab.: c. Dim.: 7.4-7.9 mm long and 7.5-7.7 mm wide. Isthmus 3.4-3.5 $\mu \mathrm{m}$ wide. Descr.: cells square-shaped in outline with widely open deep sinus. Semicells hexagonal with distinctive indentation on the apexes and slight inflation in the median part. Cell wall smooth, with a granule on each angle of the semicells. Distr: the variety of this species, Cosmarium regnesi var. polonicum (Eichler \& Gutwinski) Compère, 1976 (as Cosmarium regnesi var. montanum Schmidle, 1895), which differs from our specimens by presence of 3 acuminate granules on the center of the semicells, is known for Balbanty lake in the Polar Urals (Romanov, 2008).

Desmidium GRevillei (Kützing ex Ralfs) De Bary, 1858 (Figure 3, 1) - Ab.: c. Dim.: 25.6-26.8 mm long and 34.5-46.8 $\mathrm{mm}$ wide. Isthmus 3.4-3.5 $\mu \mathrm{m}$ wide. Descr.: cells octagonal in outline and elliptical in apical view. Sinus widely open and shallow. Cell wall smooth with two mamillated thickening on the sides of the semicells. Distr.: middle course of $\mathrm{Ob}$ river, without specifying the location (Naumenko, 1992) and Ob river near Nizhnevartovsk city (Naumenko, 1996).

Desmidium swartzi C. Agardh ex Ralfs, 1848 (Figure 3, 2) - Ab.: r. Dim.: 15.2-15.9 mm long and 39.0-39.9 mm wide. Isthmus 28.5-31.1 $\mu \mathrm{m}$ wide. Descr.: cells octagonal in outline and triangular in apical view. Sinus widely open and shallow. Cell wall smooth. Distr.: middle course of $\mathrm{Ob}$ river, without specifying the location (Naumenko, 1992), Ob river near Surgut and Nizhnevartovsk cities (Naumenko, 1996), vicinity of the Khanty-Mansiysk city (Safonova \& Shaulo, 2007) and Sarmsabun river (Naumenko \& Gidora, 2014).

*Euastrum ansatum Ehrenberg ex Ralfs, 1848 (Figure 3, 3-4) - Ab.: r. Dim.: 91.6-91.9 mm long and 47.0-50.2 mm wide. Polar lobe 23.8-24.1 

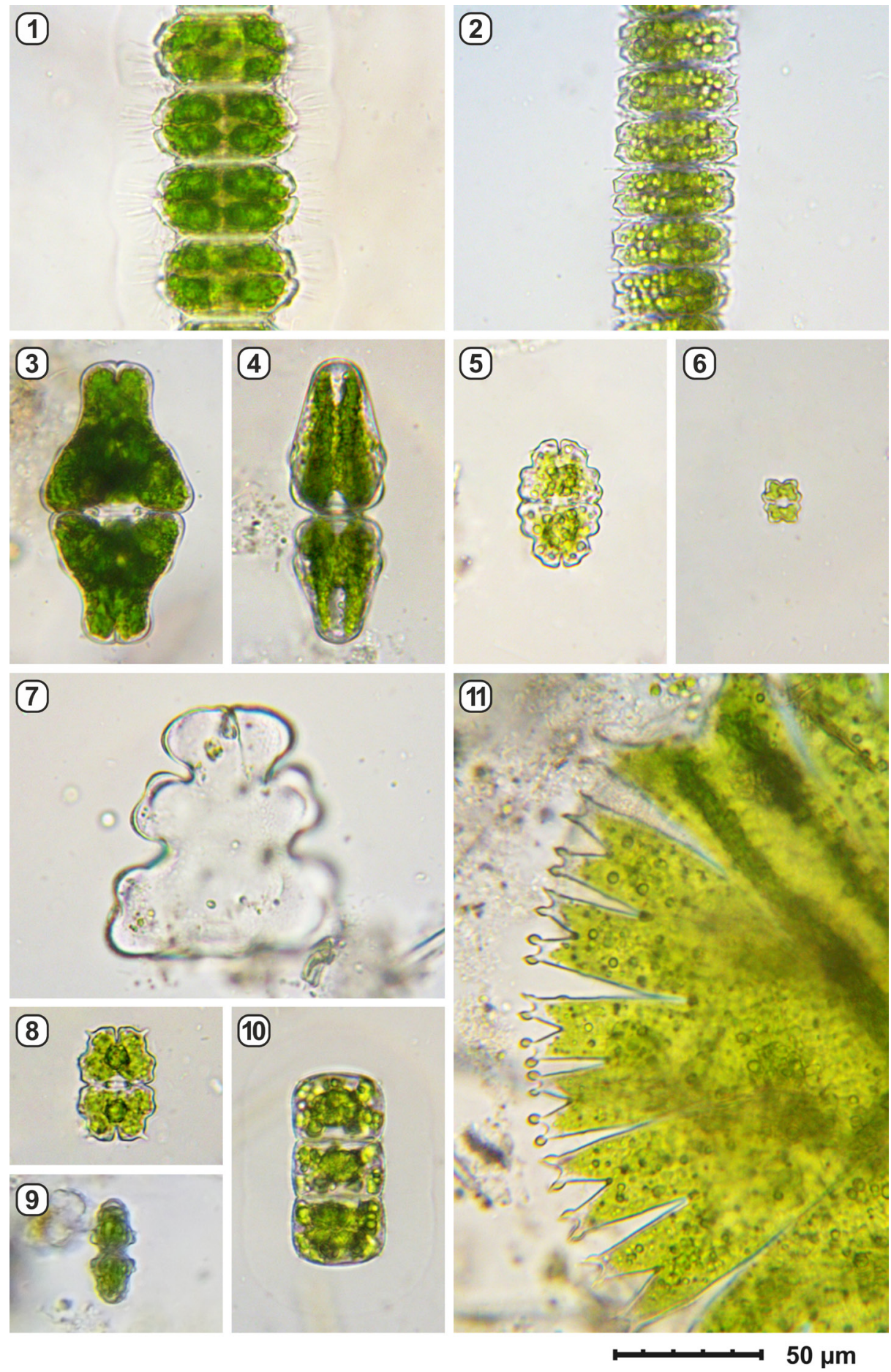

Fig. 3. 1 - Desmidium grevillei, 2 - Desmidium swartzii, 3-4 - Euastrum ansatum, 5 - Euastrum bidentatum, 6 - Euastrum gayanum, 7 - Euastrum oblongum, 8-9 - Euastrum pulchellum, 10 Hyalotheca dissiliens, 11 - Micrasterias rotata. 
$\mu \mathrm{m}$ wide. Isthmus 13.7-13.8 $\mu \mathrm{m}$ wide. Descr.: cells hexagonal in outline with linear deep sinus. Semicells pyramidal-shape with rudimental lateral and well-developed basal lobes. Polar lobe with closed deep median incision. Cell wall smooth. Distr.: the nearest regions where this species has been found are Bolshezemelskaya tundra (Luknitskaya, 2006), Yamal Peninsula (Luknitskaya, 2001), Polar Urals (Briškaite et al., 2016) and Middle Cis-Ural (Martynenko, 2017).

EUASTRUM BIDENTATUM Nägeli, 1849 (Figure 3, 5) Ab.: r. Dim.: 41.9-42.0 mm long and 27.7-28.1 $\mathrm{mm}$ wide. Polar lobe 18.9-19.2 $\mu \mathrm{m}$ wide. Isthmus 7.5-7.7 $\mu \mathrm{m}$ wide. Descr.: cells elliptical in outline with linear deep sinus. Semicells with well-developed basal and lateral lobes. Polar lobe with deep median incision and two denticulations on the angles. Cell wall granulated. Distr.: Sakurya river (Voronikhin, 1930), Matkinsky and Chaginsky floodplains (Aleksyuk et al, 1989) and vicinity of the Khanty-Mansiysk city (Safonova \& Shaulo, 2007).

*Euastrum gayanum De Toni, 1889 (Figure 3, 6) Ab.: c. Dim.: 13.3-14.5 mm long and 12.0-12.6 $\mathrm{mm}$ wide. Polar lobe $9.2-10.6 \mu \mathrm{m}$ wide. Isthmus 4.3-5.5 $\mu \mathrm{m}$ wide. Descr.: cells octagonal in outline with linear deep sinus. Semicells with well-developed basal lobes. Polar lobe with widely open shallow median concavity. Cell wall granulated. Distr.: The nearest region where this species has been found is Bolshezemelskaya tundra (Luknitskaya, 2006).

EuASTRum OBLONGum Ralfs, 1848 (Figure 3, 7) - Ab.: s. Descr.: semicell with well-developed basal and lateral lobes dividing to second order. Polar lobe with deep median incision. Cell wall smooth. Distr.: vicinity of the Vysokiy village (Safonova \& Shaulo, 2007). Note: this species was found as the only empty semicell which, however, bears all characters of the species.

*Euastrum pulchellum Brébisson, 1856 (Figure 3, 8-9) - Ab.: r. Dim.: 36.8-39.5 mm long and 25.8-28.1 mm wide. Polar lobe 17.5-19.0 $\mu \mathrm{m}$ wide. Isthmus 7.7-8.6 $\mu \mathrm{m}$ wide. Descr.: cells octagonal in outline with linear deep sinus. Semicells with median inflation furnished with three large granules. Basal and lateral lobes is well-developed. Polar lobe with deep median incision and two short spines on the angles. Cell wall granulated on the lobes margins. Distr.: the nearest regions where this species has been found are Bolshezemelskaya tundra (Luknitskaya, 2006), Polar (Briškaitè et al., 2016) and Middle Urals (Shakhmatov, 2015; Shakhmatov et al., 2018).

HyalotheCA Dissiliens Brébisson ex Ralfs, 1848 (Figure 3, 10) - Ab.: c. Dim.: 18.2-21.7 mm long and 30.6-30.8 mm wide. Isthmus 7.7-8.6 $\mu \mathrm{m}$ wide. Descr.: cells square in outline and elliptical in the apical view. Sinus inconspicuous. Cell wall smooth. Distr.: "Sibirskiye uvaly" Nature park (Naumenko, 2006) and vicinity of the Khanty-Mansiysk and Nizhnevartovsk cities (Safonova \& Shaulo, 2007).

MicRasterias Rotata Ralfs, 1848 (Figure 3, 11) - Ab.: r. Dim.: 320.2-339.8 mm long and 271.1-290.8 mm wide. Polar lobe 60.0-60.2 $\mu \mathrm{m}$ wide. Isthmus 40.3-40.9 $\mu \mathrm{m}$ wide. Descr.: cells elliptical in outline with linear deep sinus. Semicells with well-developed lateral lobes dividing to the fourth order. Polar lobe with v-shaped concavity. Cell wall smooth. Distr.: Seykoryogan river (Naumenko, 2007) and "Sibirskiye uvaly" Nature park (Naumenko \& Gidora, 2017). Note: one specimen of this alga has small drops of secreted material on its spines, which gives them a capitate shape. Other specimens have acute spines.

*Staurastrum aculeatum Meneghini, 1848 (Figure 4, 1-2) - Ab.: s. Dim.: $40.9 \mathrm{~mm}$ long and $37.1 \mathrm{~mm}$ wide. Isthmus $17.1 \mu \mathrm{m}$ wide. Descr.: cell with long slightly convergent horizontal processes, furnished with granules, bifurcate spines and denticulations. In apical view the cell is 3-radiate. Sinus widely open. Distr.: the nearest site where this species has been found is lower course of Ob river (Naumenko, 1992).

*StauRastrum aRcuatum var. SUbavicula (West) Coesel et Meesters, 2013 (Figure 4, 3-5) - Ab.: r. Dim.: 33.5-33.9 mm long and 20.9-26.9 $\mathrm{mm}$ wide without processes (with processes 45.6-49.7 $\mathrm{mm}$ long and 45.3-48.5 mm wide). Isthmus 12.3-13.8 $\mu \mathrm{m}$ wide. Descr.: Semicells with two series of short processes. In the apical view the cells are 3-radiate with 9 processes. Sinus widely open. Cell wall granulated. Note: the similar species Staurastrum furcatum Brébisson, which can be confused with $S$. arcuatum var. subavicula, was reported from Naroda and Sakurya rivers (Voronikhin, 1930). Accordingly, this species may be not new to the region. 

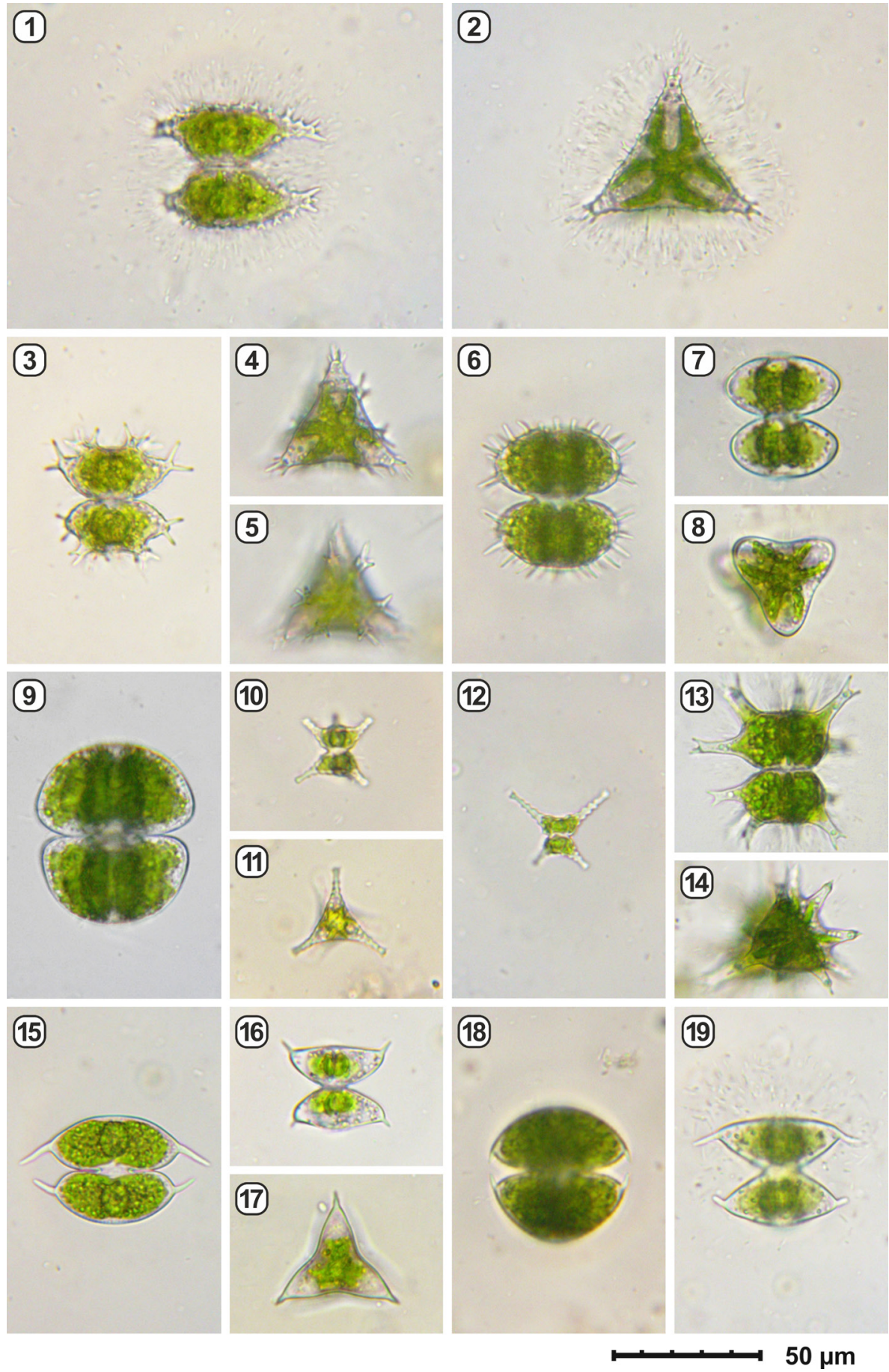

Fig. 4. 1-2 - Staurastrum aculeatum, 3-5 - Staurastrum arcuatum var. subavicula, 6-Staurastrum gladiosum, 7-8 - Staurastrum muticum, 9 - Staurastrum orbiculare, 10-11-Staurastrum paradoxum, 12 - Staurastrum tetracerum, 13-14 - Staurastrum tohopekaligense, 15 - Staurodesmus convergens, 16-17 - Staurodesmus dejectus, 18 - Staurodesmus dickiei var. circularis, 19 - Staurodesmus glaber. 
Staurastrum gLadiosum W.B. Turner, 1885 (Figure 4, 6) - Ab.: s. Dim.: $47.2 \mathrm{~mm}$ long and 40.1 $\mathrm{mm}$ wide without spines (with spines $54.0 \mathrm{~mm}$ long and $50.5 \mathrm{~mm}$ wide). Isthmus $16.3 \mu \mathrm{m}$ wide. Descr.: cell without processes, 3-radiate in apical view. Sinus widely open. Cell wall furnished by long spines. Distr.: Sakurya river (Voronikhin, 1930), the middle course of Ob river, without specifying the location (Naumenko, 1992) and Ob river near Surgut city (Naumenko, 1996).

STAURASTRUM MUTICUM Brébisson, 1848 (Figure 4, 7-8) - Ab.: r. Dim.: 37.2-38.6 mm long and 34.5-35.9 mm wide. Isthmus 10.1-10.5 $\mu \mathrm{m}$ wide. Descr.: cells without processes, 3-radiate with broadly rounded angles in apical view. Sinus widely open. Cell wall smooth. Distr.: Vakh river (Skorobogatova, 2018).

STAURASTRUM ORBICULARE Meneghini ex Ralfs, 1848 (Figure 4, 9) - Ab.: r. Dim.: 55.2-58.6 mm long and 47.6-54.2 mm wide. Isthmus 14.7-19.6 $\mu \mathrm{m}$ wide. Descr.: cells without processes, elliptical in outline and 3-radiate with broadly rounded angles in apical view. Sinus linear on the greater part. Cell wall smooth. Distr.: the middle course of $\mathrm{Ob}$ river near Belogorye village (Naumenko, 1996), "Sibirskiye uvaly" Nature park (Naumenko, 2006), Sarmsabun river (Naumenko \& Gidora, 2014) and Vakh river (Skorobogatova, 2018).

STAURASTRUM PARADOXUm Meyen ex Ralfs, 1848 (Figure 4, 10-11) - Ab.: r. Dim.: 9.4-16.3 $\mathrm{mm}$ long and $7.6-12.5 \mathrm{~mm}$ wide without processes (with processes 14.1-23.1 $\mathrm{mm}$ long and 18.6-23.7 $\mathrm{mm}$ wide). Isthmus 5.7-5.8 $\mu \mathrm{m}$ wide. Descr.: cells with long divergent processes, furnished with granules, 3-radiate in apical view. Sinus widely open. Distr.: Konda river (Naumenko, 1988a), Demyanka river (Naumenko, 1988b), the middle course of Ob river, without specifying the location (Naumenko, 1992), "Sibirskiye uvaly" Nature park (Naumenko, 2006), Vakh river (Skorobogatova, 2018).

STAURASTRUm tetracerum Ralfs ex Ralfs, 1848 (Figure 4, 12) - Ab.: s. Dim.: $12.4 \mathrm{~mm}$ long and $11.7 \mathrm{~mm}$ wide without processes (with processes $27.6 \mathrm{~mm}$ long and $33.8 \mathrm{~mm}$ wide). Isthmus $6.3 \mu \mathrm{m}$ wide. Descr.: cell with long divergent processes, furnished with granules, 2-radiate in apical view. Sinus widely open. Distr.: the middle course of $\mathrm{Ob}$ river, without specifying the location (Naumenko, 1992), Ob river near
Nizhnevartovsk city (Naumenko, 1996) and Vakh river (Skorobogatova, 2018).

*Staurastrum tohopeKaligense Wolle, 1885 (Figure 4, 13-14) - Ab.: s. Dim.: 36.9 mm long and $28.7 \mathrm{~mm}$ wide without processes (with processes $57.1 \mathrm{~mm}$ long and $54.7 \mathrm{~mm}$ wide). Isthmus 15.9 $\mu \mathrm{m}$ wide. Descr.: semicells with two series of long processes, in apical view 3-radiate with 9 processes. Sinus widely open. Cell wall smooth. Distr.: the nearest region where this species has been found is Polar Urals (Briškaite et al., 2016).

STAURODESMUS CONVERGENS (Ehrenberg ex Ralfs) S. Lillieroth, 1950 (Figure 4, 15) - Ab.: c. Dim.: 34.9-38.5 mm long and 38.5-46.7 mm wide without processes (with processes 61.6-69.4 mm wide). Isthmus 10.0-12.6 $\mu \mathrm{m}$ wide. Descr.: semicells elliptical in outline with long spines on the poles, 2-radiate in apical view. Sinus linear on the greater part. Cell wall smooth. Distr.: "Sibirskiye uvaly" Nature park (Naumenko, 2006) and vicinity of the Vysokiy village (Safonova \& Shaulo, 2007).

STAuRodesmus DEJectus (Brébisson) Teiling 1954 (Figure 4, 16-17) - Ab.: c. Dim.: 24.7-27.0 mm long and $28.2-33.4 \mathrm{~mm}$ wide without spines (with spines $33.5-42.6 \mathrm{~mm}$ wide). Isthmus 7.9-10.2 $\mu \mathrm{m}$ wide. Descr.: semicells bowl-shaped in outline with short spines on the angles, 3-radiate in apical view. Sinus widely open. Cell wall smooth. Distr.: Sakurya river (Voronikhin, 1930).

*Staurodesmus dickiei var. circularis (W.B. Turner) Croasdale, 1957 (Figure 4, 18) - Ab.: s. Dim.: $43.9 \mathrm{~mm}$ long and $42.5 \mathrm{~mm}$ wide. Isthmus 19.1 $\mu \mathrm{m}$ wide. Descr.: Semicells semicircular in outline with short spines on the basal angles, 3 -radiate in apical view. Sinus widely open. Cell wall smooth. Distr.: the nearest region where this species has been found is Middle Urals (Shakhmatov, 2015).

*STaurodesmus glaber (Ralfs) Teiling, 1948 (Figure 4, 19) - Ab.: c. Dim.: 33.2-34.9 mm long and 38.5-39.8 $\mathrm{mm}$ wide without spines (with spines $52.3-55.5 \mathrm{~mm}$ wide). Isthmus 10.1-12.8 $\mu \mathrm{m}$ wide. Descr.: semicells triangular in outline with long spines, in apical view 3-radiate. Sinus widely open. Cell wall smooth. Distr.: the nearest region where this species has been found is Gulf of Ob (Naumenko, 1992).

Xanthidium antilopaeum Kützing, 1849 (Figure 5, 1) - Ab.: c. Dim.: 53.4-57.6 mm long and 
49.3-50.2 $\mathrm{mm}$ wide without spines (with spines 70.4-74.9 $\mathrm{mm}$ long and 75.5-76.5 mm wide). Isthmus 19.4-20.7 $\mu \mathrm{m}$ wide. Descr.: semicells hexagonal in outline with 4 pairs of long spines on the angles. Sinus linear. Cell wall smooth. Distr.: "Sibirskiye uvaly" Nature park (Naumenko, 2006), vicinity of the Vysokiy village (Safonova \& Shaulo, 2007), Sarmsabun river (Naumenko \& Gidora, 2014) and Vakh river (Skorobogatova, 2018).
Xanthidium antilopaeum f. polymazum (Nordstedt) Petlovany, 2015 (Figure 5, 2) - Ab.: s. Dim.: 78.6 $\mathrm{mm}$ long and $71.9 \mathrm{~mm}$ wide without spines (with spines $110.6 \mathrm{~mm}$ long and $106.4 \mathrm{~mm}$ wide). Isthmus $27.3 \mu \mathrm{m}$ wide. Descr.: Semicells hexagonal in outline with 4 pairs of long spines on the angles. Sinus linear. Cell wall smooth with row of granules near the apexes. Distr.: "Sibirskiye uvaly" Nature park (Naumenko \& Ptukhina, 2013).
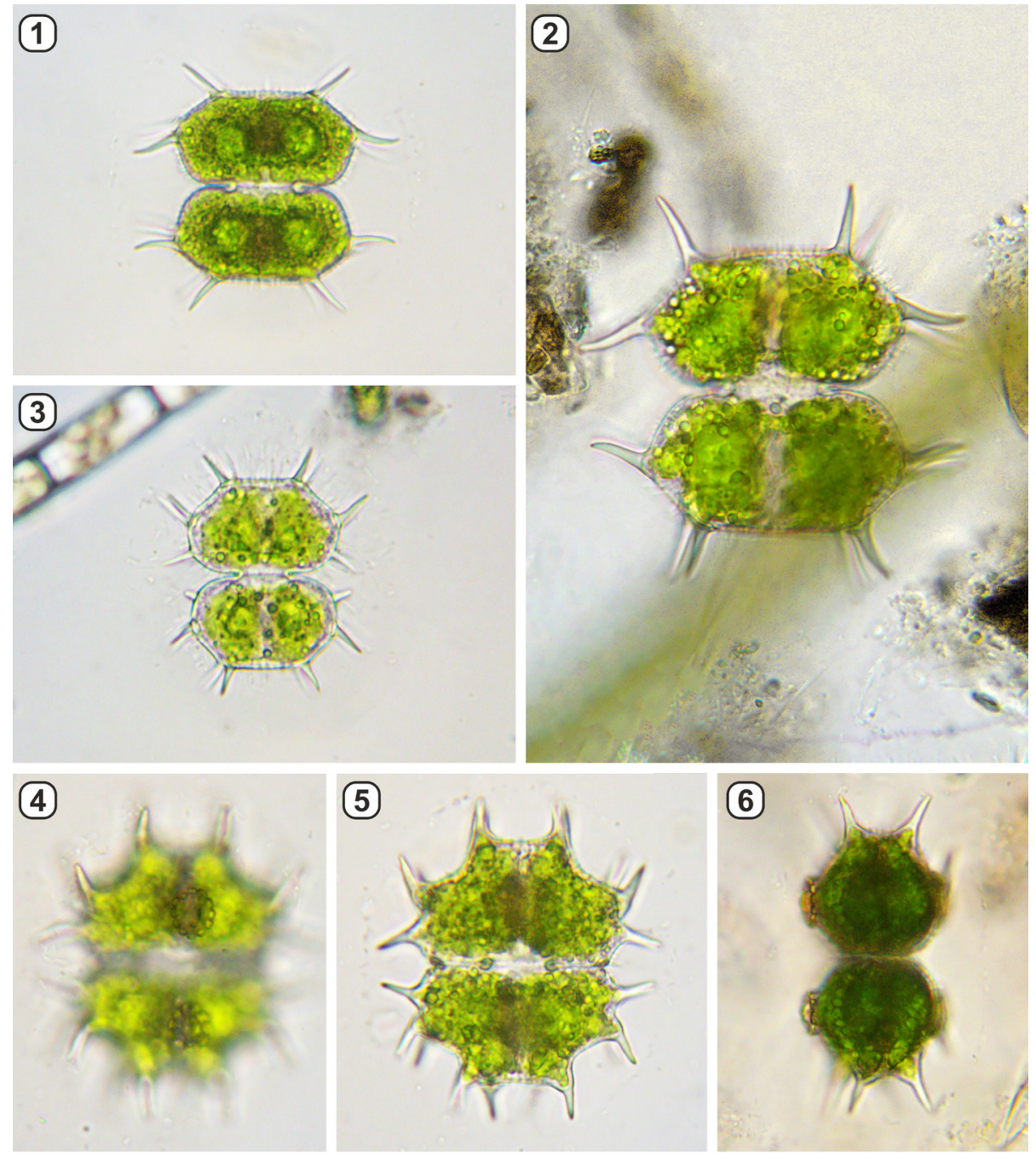

$50 \mu \mathrm{m}$

Fig. 5. 1 - Xanthidium antilopaeum, 2 - Xanthidium antilopaeum f. polymazum, 3 - Xanthidium cristatum, 4-6 - Xanthidium uncinatum. 
*XANTHidium CRISTAtum Brébisson ex Ralfs, 1848 (Figure 5, 3) - Ab.: r. Dim.: 51.5-53.3 mm long and $39.7-40.4 \mathrm{~mm}$ wide without spines (with spines $67.6-68.0 \mathrm{~mm}$ long and $53.6-54.7 \mathrm{~mm}$ wide). Isthmus $14.1-15.0 \mu \mathrm{m}$ wide. Descr.: semicells hexagonal in outline with 4 pairs of long spines on the lateral and the apical angles and with single spine on the basal angles. Sinus widely open. Cell wall smooth. Distr.: the nearest regions where this species has been recorded is Bolshezemelskaya tundra (Luknitskaya, 2006), Polar (Briškaitè et al., 2016) and Middle Urals (Shakhmatov, 2015, Shakhmatov et al., 2018).

*Xanthidium uncinatum (Ralfs) Stastny, Skaloud et Neustupa, 2013 (Figure 5, 4-6) - Ab.: c. Dim.: 68.2-70.8 $\mathrm{mm}$ long and $55.8-58.1 \mathrm{~mm}$ wide without spines (with spines 85.4-87.9 mm long and $77.3-79.7 \mathrm{~mm}$ wide). Isthmus $16.8-18.6 \mu \mathrm{m}$ wide. Descr.: semicells hexagonal in outline with 4 pairs of long thick spines on the lateral and the apical angles and with single thick spine on the basal angles. Sinus linear. Cell wall smooth, with ornamentation on inflation in the midregion of the semicells. Distr.: the nearest regions where this species has been found is Bolshezemelskaya tundra (Luknitskaya, 2006), Polar (Patova \& Demina, 2007) and Middle Urals (Shakhmatov, 2015, Shakhmatov et al., 2018) and Middle CisUral (Martynenko, 2017).

\section{DISCUSSION}

In total, 35 species and subspecific taxa of desmid algae, which belong to two families and nine genera were found in studied area. 27 species, which consist $77 \%$ of the discovered diversity, belong to family Desmidiaceae, where genus Staurastrum is the most species-rich in the studied area (eight species; $23 \%$ ) and Euastrum is on the second position (five species; 14.4\%). Other eight species (23\%) belong to the Closteriaceae family, which is represented in the study only by the genus Closterium.

Twelve species (Closterium costatum, Cosmarium regnesi, Euastrum ansatum, E. gayanum, E. pulchellum, Staurastrum aculeatum, S. arcuatum var. subavicula, S. tohopekaligense, Staurodesmus dickiei var. circularis, S. glaber, Xanthidium cristatum, X. uncinatum) and one variety (Closterium closterioides var. intermedium) are new for KMAO-Yugra, but these taxa are known from the other parts of the West Siberian Plain or adjacent regions, such as the Polar, Subpolar, Northern and Middle Urals.

Another three species and two varieties - Closterium jenneri var. cynthia, Euastrum oblongum, Staurastrum muticum, Staurodesmus dejectus, Xanthidium antilopaeum f. polymazum - are considered rare in the region and are predominantly known from its central and eastern parts. The finding of them near the western border of the region clearly indicates their wider distribution in KMAO-Yugra, than it has been previously thought.

The species found in the studied area obviously make up only a small part of the desmid flora in Yugorsk vicinities. However, the fact that it contains many rare and previously unreported species makes its further study necessary for a better understanding of algal diversity in the Khanty-Mansi Autonomous Okrug.

\section{ACKNOWLEDGEMENTS}

We would like to express our gratitude to A. G. Paukov (Ural Federal University, Ekaterinburg, Russia) and an anonymous reviewer for reading our manuscript, linguistic correction and for his useful comments. We also would like to thank A. F. Luknitskaya (V. L. Komarov Botanical Institute RAS, St. Petersburg, Russia) for invaluable help with determination of some species.

\section{REFERENCES}

Aleksyuk, V. A., Semenova, L. A. \& Skrypkina, S. V. 1989. Algoflora of the Ob-Irtysh basin flood plain system. Hydrobiological characteristics of the Ural water reservoirs: collection of scientific works. Sverdlovsk. Pp. 3-12. (In Russian).

Boch, M. S. \& Masing, V. V. 1979. Mire ecosystems in the USSR. Moscow, Nauka. 188 pp. (In Russian).

Briškaite, R., Patova, E. \& Juzènas, S. 2016. Desmid flora in the lakes of the Khrebtovyi Nature Reserve in the Polar Ural (Russia). Botanica Lithuanica 22(2): 113-122. https://doi.org/10.1515/botlit-2016-0012

Butakova, E. A. \& Stanislavskaya, E. V. 2004. Periphyton of the Iset river basin (Sverdlovsk region). Botanicheskiy Zhurnal 89(9): 1420-1436 (In Russian).

Coesel, P. F. M. \& Meesters, K. J. 2007. Desmids of the lowlands. Zeist, KNNV Publishing. $351 \mathrm{pp}$. https: / /doi.org/10.1163/9789004277922

Coesel, P. F. M. \& Meesters, K. J. 2013. European flora of the desmid genera Staurastrum and Staurodes- 
mus. Zeist, KNNV Publishing. 357 pp. https://doi. org/10.1163/9789004277915

Guiry, M. D. \& Guiry, G. M. 1996-2018. AlgaeBase. World-wide electronic publication. National University of Ireland, Galway. URL: http://www. algaebase.org (Accessed at 10 December 2018).

Gvozdeckiy, N. A. \& Mikhaylov, N. I. 1978. Physical geography of the USSR. Asian part. Moscow, Geografgiz. 512 pp. (In Russian).

Kosinskaya, E. K. 1960. Flora of cryptogamic plants of USSR. Conjugates. Desmids algae. 5 (2) MoscowLeningrad, USSR Academy of Sciences Publishing House. 511 pp. (In Russian).

Luknitskaya, A. F. 1999. De Mesotaenialibus et Desmidialibus in parte boreali-orientali tundrae Bolshezemelskaja dictae (prope opp. Vorkuta) vigentibus notula. Novitates Systematicae Plantarum non Vascularium 33: 24-27. (In Russian).

Luknitskaya, A. F. 2001. Ch1orophyta (Conjugatae) aquatorium nonnullarum in parte australi paeninsulae Jamal. Novitates Systematicae Plantarum non Vascularium 34: 30-34. (In Russian).

Luknitskaya, A. F. 2006. Synopsis of conjugate flora (Streptophyta, Zygnematophyceae) of the north Russia. Novitates Systematicae Plantarum non Vascularium 40: 49-82. (In Russian).

Martynenko, N. A. 2017. Culture collection of desmids from the mires of the Perm territory (Russia). Transactions of IBIW RAS 79(82): 110-114. (In Russian). https:/ /doi.org/10.24411/0320-35572017-10033

Naumenko, Y. V. 1988a. Phytoplankton of the Konda river. Izvestija Sibirskogo otdelenija Akademii nauk SSSR. Serija biologicheskikh nauk 2: 66-71. (In Russian).

Naumenko, Y. V. 1988b. The characteristic structure of the phytoplankton of the Demjanka river. $I z-$ vestija Sibirskogo otdelenija Akademii nauk SSSR. Serija biologicheskikh nauk 3: 48-52. (In Russian).

Naumenko, Y. V. 1992. Species composition of desmids (Desmidiales, Chlorophyta) of the Ob river. Botanicheskiy zhurnal 77, 11: 89-93. (In Russian).

Naumenko, Y. V. 1996. Ad floram desmidialium fluminis Ob. Novitates Systematicae Plantarum non Vascularium 31: 43-45. (In Russian).

Naumenko, Y. V. 2006. Algoflora of Sibirskie Uvaly Nature Reserve. Biological Resources and Nature Management 9: 159-175. (In Russian).

Naumenko, Y. V. 2007. First data on algae of "Sibirskiye uvaly" Nature Park (West Siberia, Russia). Algologia 17(2): 230-236. (In Russian).

Naumenko, Y. V. \& Gidora, O. Y. 2014. Species diversity of algae in Sarm-Sabun river (Western Siberia). Proceedings of Voronezh State University. Series: Chemistry. Biology. Pharmacy 2: 76-85. (In Russian).

Naumenko, Y. V. \& Gidora, O. Y. 2017. Micrasterias C. Agarth ex Ralfs species in the natural park "Sibirskiye Uvaly” (West Siberia, Russia). Ukrainian
Journal of Ecology 7(2): 116-119. https://doi. org/10.15421/2017_58

Naumenko, Y. V. \& Ptukhina, O. Y. 2013. Desmids algae (Desmidiales) of the natural park "Sibirskie Uvaly", West Siberia, Russia. Turczaninowia 16(2): 81-83 (In Russian).

Palamar-Mordvintseva, G. M. 1982. The key to freshwater algae of the USSR. Conjugatophyceae. Desmidiales. 11(2). Leningrad, Nauka. 620 pp. (In Russian).

Patova, E. N. \& Demina, I. V. 2007. Algae of other divisions. In: Getsen M. V. (ed.). Biodiversity of the Polar Ural ecosystems. Syktyvkar. 252 pp (In Russian).

Romanov, R. E. 2008. Algae and cyanobacteria from water systems of the projected "Manyinsky" Natural Park. Bulletin of Forest and Landscape Ecology 8: 58-65 (In Russian).

Safonova, T. A. \& Shaulo, S. P. 2006. New and rare species of algae for the Western Siberia. Turczaninowia 9 (3): 102-108. (In Russian).

Safonova, T. A. \& Shaulo, S. P. 2007. The addition to algoflora of the water bodies of the middle taiga of the West Siberia. Turczaninowia 10(2): 50-71. (In Russian).

Shakhmatov, A. S. 2015. First information on the conjugating green algae (Streptophyta, Conjugatophyceae) species composition in overgrown lakes of the southern Sverdlovsk region. Novitates Systematicae Plantarum non Vascularium 49: 117-123. (In Russian).

Shakhmatov, A. S., Pavlovskiy, E. V. \& Paukov, A. G. 2018. Desmid algae (Charophyta: Conjugatophyceae) of Ekaterinburg, Middle Urals, Russia. Folia Cryptogamica Estonica 55: 7-15. https:// doi.org/10.12697/fce.2018.55.02

Skorobogatova, O. N. \& Naumenko, Y. V. 2009. Genus Closterium Ehr. in the phytoplankton of the Vakh river (West Siberia). Problems of Botany of South Siberia and Mongolia: Proceedings of 8th International Scientific-Practical Conference (Barnaul, 19-22 Oktober 2009). Barnaul. 480 pp. (In Russian).

Skorobogatova, O. N. 2013. Algological assessment of the surface water quality in the Northern Sosva River Basin. In: Kozin V. V., Korkina E. A. (eds) Complex assessment of the state of water bodies and water resources in the North Sosva river basin. Nizhnevartovsk, Nizhnevartovsk State University. 143pp. (In Russian).

Skorobogatova, O. A. 2018. Taxonomic composition of phytoplankton in the Vakh River (Western Siberia). IOP Conference Series: Earth and Environmental Science 138 (1): 012017. https://doi. org/10.1088/1755-1315/138/1/012017

Skvortzow, B. W. 1927. Einige Süßwasseralgen aus Tobolsk (Sibirien). Hedwigia 67: 246.

Snitko, L. V. \& Sergeeva, R. M. 2003. Algae of the South Urals different types water bodies. Miass, Ilmen State Reserve. 166 pp. (In Russian). 
Sterlyagova, N. I. 2008. Desmids in mountain lakes of the subpolar Urals. Biologia 63(6): 911-916. https://doi.org/10.2478/s11756-008-0142-8

Voronikhin, N. N. 1930. Algae of the Polar and the Northern Urals. Proceedings of the Leningrad Society of Naturalist 60(3): 1-71. (In Russian).
Yarushina, M. I., Tanaeva, G. V. \& Eremkina, T. V. 2004. Algal flora of the Chelyabinsk region water bodies. Ekaterinburg, IPAE. 308 pp. (In Russian). 